\title{
Novos táxons e combinações em Viguiera (Asteraceae - Heliantheae) ${ }^{1}$
}

\author{
New taxa and combinations in Viguiera (Asteraceae - Heliantheae)
}

\author{
Mara Angelina Galvão Magenta ${ }^{2}$, José Rubens Pirani ${ }^{3}$ \\ \& Claudio Augusto Mondin ${ }^{4}$
}

\begin{abstract}
Resumo
O gênero Viguiera Kunthestá representado por 35 espécies no Brasil. O presente estudo apresenta quatro novas espécies e três novas combinações de Viguiera ocorrentes no país. São providos também comentários taxonômicos, informações fenológicas, distribuição geográfica, habitat de ocorrência e ilustrações das novas espécies.

Palavras-chave: Brasil, cerrado, Compositae, Helianthinae, Rhysolepis.
\end{abstract}

\begin{abstract}
The genus Viguiera Kunth is represented in Brazil by 35 species. Four new species and three new combinations of Viguiera in Brazil are presented. Taxonomic comments and information on phenology, geographic distribution, habitat, and illustrations are also provided for the new species.
\end{abstract}

Keywords: Brazil, “cerrado”, Compositae, Helianthinae, Rhysolepis.

\section{Introdução}

Viguiera Kunth, um gênero de ocorrência exclusiva na região Neotropical, apresenta, em seu sentido amplo, a maior riqueza em espécies entre os representantes da subtribo Helianthinae (tribo Heliantheae, Asteraceae). A mais abrangente revisão do gênero foi feita por Blake (1918). Atualmente, há várias propostas de segregação de Viguiera em gêneros menores, com base em estudos moleculares (Schilling \& Panero 2002).

Robinson \& Moore (2004) propuseram a transferência das espécies de Viguiera da América do Sul para Rhysolepis S.F. Blake, com base em dados morfológicos. Este último exibe páleas do receptáculo (ao menos as periféricas das flores do disco) com base acentuadamente gibosa, transversalmente corrugadas e com ápice pungente, cipselas das flores da periferia do disco conspicuamente assimétricas, com carpopódio unilateral e pápus facilmente destacável, características compartilhadas com Aldama La Llave \& Lex., também da América Central. Contudo, o estudo taxonômico das espécies de Viguiera ocorrentes no Brasil realizado por Magenta (2006) não sustenta a circunscrição proposta por
Robinson \& Moore (2004). Com base neste estudo as plantas da América do Sul, tradicionalmente incluídas em Viguiera, apresentam receptáculo com páleas naviculares, que envolvem apenas parcialmente a flor, com ápice agudo ou, às vezes, obtuso ou truncado, carpopódio bilateral assimétrico geralmente delgado e pápus persistente na grande maioria das espécies, incluindo todas as do Brasil. Isso constitui marcante contraste morfológico com a circunscrição de Rhysolepis. A análise filogenética baseada em caracteres morfológicos (Magenta 2006) não corrobora a nova circunscrição genérica proposta, já que Rhysolepis emergiu em um clado incluindo representantes do subgênero mexicano Amphilepis S.F. Blake e das espécies andinas da América do Sul ou, juntamente com Aldama, como grupo-irmão das Viguiera da América do Sul, além de espécies do gênero Helianthus L. . Por outro lado, a espécie típica do gênero, V. dentata (Cav.) Spreng., foi posicionada nessa análise filogenética em um clado basal, formado por plantas mexicanas como Bahiopsis Kellogg, Hymenostephium Benth, V. cordifolia A.Gray e Simsia dombeyana DC. Assim, os resultados desse estudo cladístico, embora preliminares, apontaram um

\footnotetext{
Parte da tese de Doutorado da primeira autora, Universidade de São Paulo.

${ }^{2}$ Universidade Santa Cecília, Depto. Botânica, R. Oswaldo Cruz 277, Boqueirão, 11045-90, Santos, SP, Brasil.

${ }^{3}$ Universidade de São Paulo, Depto. Botânica, Instituto de Biociências, R. do Matão, Trav. 14, 321, 05508-900, São Paulo, SP, Brasil.

${ }^{4}$ Pontifícia Universidade Católica do Rio Grande do Sul, Depto. Biodiversidade e Ecologia, Av. Ipiranga, 6681, Prédio 12, 90619-900, Porto Alegre, RS, Brasil.

Autor para correspondência: maramagenta@unisanta.br
} 
provável polifiletismo de Viguiera, como atualmente circunscrito.

Além disso, estudos filogenéticos baseados em sequências de $c p$ DNA (Schilling \& Panero 1996) corroboram os resultados da análise citada, mostrando que os gêneros Aldama e Rhysolepis são estreitamente relacionados. A estreita relação com Helianthus, evidenciada nas análises, sugere que outras investigações mais aprofundadas são necessárias para elucidar o posicionamento filogenético das espécies sul-americanas desse grupo. No quadro atual, fica patente a improcedência de se acatar a proposta de incluir as espécies de Viguiera em Rhysoplepis. E, por isso, os táxons são tratados aqui de modo conservador.

\section{Material e Métodos}

O tratamento taxonômico de Viguiera no Brasil (Magenta 2006) foi baseado principalmente no estudo de exemplares dos seguintes herbários: A, BHCB, BM, BOTU,BR, C,CEN,CESJ,CETEC, CGMS,COR,CPAP, CTES, E, ESA, FUEL, GH, HAS, HASU, HEPH, HRB, HRCB, HUCS, HUEFS, HUEPG, HUFU, IBGE, ICN, IPA, K, LP, LPB, M, MA, MBM, MPUC, NY, P, PACA, PEL, R, RB,S, SGO, SMDB, SP, SPF, SPFR, SPSF, UB, UEC, UFG, UFLA, UFMT, UPF, US, VEN(Thiers 2009); e na observação de populações no campo. As siglas de todos os herbários que tiveram os materiais tipo examinados é seguida de um ponto de exclamação; aqueles materiais dos quais se avaliou imagens digitais têm a sigla de herbário seguida por *. Foi adotado o conceito taxonômico de espécie, no qual espécie é uma categoria que permite o agrupamento de indivíduos, sendo tratados como espécies os táxons que apresentam descontinuidade morfológica entre si (Stace 1980; Snaydon 1984). As novas combinações são baseadas na circunscrição de Viguiera segundo Blake (1918). A terminologia foi baseada em Radford et al. (1974), Weberling (1989), Barroso et al. (1991), Bremer (1994); Haris \& Haris (2001) e Roque et al. (2009).

\section{Resultados e Discurssão}

\section{Espécies novas}

Viguiera knobiana Mondin \& Magenta, sp. nov. Tipo: BRASIL. RIO GRANDE DO SUL: Toropi, estrada para Jari, 9.IV.2002, fl. e fr., A. Knob \& S. Bordignon 7163 (holótipo ICN!).

Fig. 1

Viguiera anchusifolia (DC.) Baker similis sed ab ea involucro biseriatis, foliis ovatis vel oblongoellipticis, indumento hispido in caulis, ramis, foliis, pedunculis et bracteis involucralibus differt.
Subarbusto ereto, ca. 0,8 m alt., ramificado superiormente. Caule folhoso até o ápice, cilíndrico, estriado, híspido, indumento mais denso em direção ao ápice. Folhas simples, opostas ou subopostas, sésseis ou subsésseis; pecíolo ausente ou até ca. 0,1 cm compr.; lâminas 6-9×2,6-4,5 cm, levemente discolores, membranáceas ou papiráceas, ovais ou oblongo-elípticas, base arredondada, ápice agudo, margem inteira na metade inferior, paucisserrulada a paucisserreada na metade superior, híspidas, face abaxial pontuado-glandulosa; trinérveas acima da base, depois peninérveas. Capítulos radiados, solitários ou aos pares no ápice dos ramos, terminais e axilares; pedúnculos 2,5-7,5 cm compr., híspidos, ebracteados ou com uma bráctea linear-lanceolada, 0,5-1 cm compr. Invólucro hemisférico, 7-8 mm compr., ca. 10 mm diâm.; brácteas involucrais 2seriadas, oblongo-lanceoladas, ápice calosomucronado, rígidas na base, membranáceas no ápice, quinquenérveas a multinérveas, as da série externa 6-7 × ca. 1,5 mm, densamente híspidas a vilosas e pontuado-glandulosas, as da série interna 7,5-9 $\times$ ca. $2 \mathrm{~mm}$, dorso levemente estrigoso e pontuadoglanduloso, margem longamente ciliado-vilosa; receptáculo convexo, páleas $6,5-7,5 \times$ ca. $2 \mathrm{~mm}$, conduplicadas, carenadas, oblongo-lanceoladas, ápice acuminado ou mucronulado, margem denticulada no ápice, levemente estrigosas e pontuado-glandulosas na parte superior. Flores do raio em 1 série, neutras, ca. 8 por capítulo, corola 13 $18 \times 4-5 \mathrm{~mm}$, amarela, liguliforme, tubo ca. $0,7 \mathrm{~mm}$ compr., limbo estreitamente elíptico ou estreitamente oblongo, ápice inteiro a tridentado, pontuadoglanduloso no tubo e na face abaxial do limbo; flores do disco ca. 40 por capítulo, corola 4-4,5 mm compr., amarela, tubulosa, tubo ca. $1 \mathrm{~mm}$ compr., pentadentadas, lacínias 1-1,3 mm compr., tubo e ápice das lacínias levemente estrigosos; anteras com tecas enegrecidas, apêndice triangular, pontuadoglanduloso, base aguda; estilete bífido, ápice dos ramos pubérulo. Cipselas 3,5-4 mm compr., obovóides, levemente comprimidas, seríceas, castanhas. Pápus formado por duas aristas paleáceas de 2,5-3 mm compr., escamas intermediárias 1-1,5 mm compr., livres entre si, ápice lacerado.

A espécie é conhecida somente pelo exemplar-tipo, não existindo outras coleções disponíveis nos herbários consultados.

Espécie endêmica da região central do Rio Grande do Sul, inserida no bioma Pampa, crescendo entre a vegetação arbustiva e em solos secos e pedregosos. Foi coletada com flores e frutos em abril. 


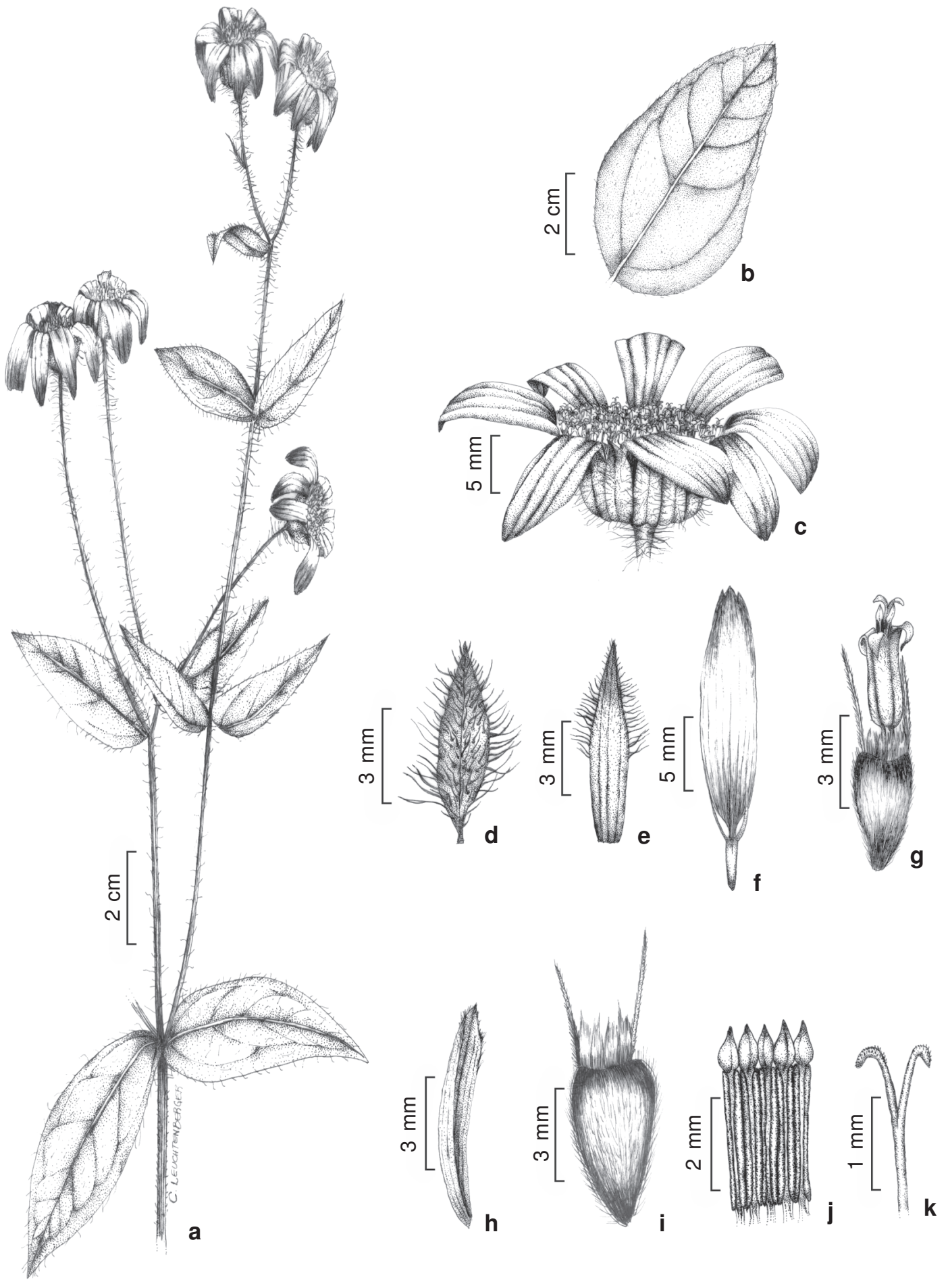

Figura 1 - Viguiera knobiana Mondin \& Magenta - a. ramo florido; b. folha basal; c. capítulo; d-e. brácteas involucrais; f. corola do raio; g. flor do disco; h. pálea; i. cipsela; j. anteras; k. ápice do estilete (Knob \& Bordignon 7163).

Figure 1 - Viguiera knobiana Mondin \& Magenta - a. flowering branch; b. basal leaf; c. capitulum; d-e. phyllaries; f. ray corolla; g. disc floret; h. palea; i. cypsela; j. anthers; k. style arms (Knob \& Bordignon 7163). 
O epíteto é uma homenagem ao botânico Alberto Knob, do Instituto Geobiológico La Salle, um dos coletores do tipo.

Ao que tudo indica, é extremamente rara na natureza, necessitando ter seu hábitat protegido para evitar que seja extinta. Trata-se de uma área pouco visitada por botânicos, havendo por isso poucos registros de plantas em herbários, além de ser explorada pela agropecuária, o que contribui para a destruição do hábitat natural.

Viguiera knobiana caracteriza-se, sobretudo, pelas folhas ovais e indumento híspido do caule, folhas, pedúnculo e brácteas involucrais. Diferencia-se de $V$. anchusifolia por esta apresentar número maior de séries de brácteas involucrais, folhas com lâmina lanceolada a estreitamenteoblonga e indumento estrigoso. Distingue-se de $V$. squalida S. Moore por esta apresentar capítulos com invólucro campanulado, brácteas involucrais tuberculadas na margem e na metade inferior e cipsela glabrescente, com aristas de porção basal gibosa. Apresenta semelhança também com $V$. bakeriana S.F. Blake, porém esta espécie apresenta invólucros maiores, com 12-20 mm de diâmetro, 10-12 (raramente 15-16) flores no raio e pela cipsela com indumento levemente estrigoso no ápice.

Viguiera meridionalis Magenta, sp. nov. Tipo: BRASIL. RIO GRANDE DO SUL: Soledade, 2.IV.1979, fl. e fr., K. Hagelund s.n. (holótipo ICN 12804!; fotografia do holótipo SPF!). Fig. 2

$A$ Viguiera procumbens S.F.Blake affinis, sed bracteis interioribus saepe longi-acuminatis et pappi aristis rigidulis carinatis cum squamulis lateralis unitis differt.

Ervas perenes a subarbustos, ca. $1 \mathrm{~m}$ alt.; ramos aéreos eretos, cilíndricos a levemente tetragonais, estriados, esparsamente estrigosos, entrenós 0,5-4 cm compr.; sistema subterrâneo desconhecido. Folhas alternas, sésseis ou pecíolo 1-5 mm compr., viloso; lâmina 3-6×2-3 cm, oval, base arredondada a obtusa, às vezes levemente cuneada, ápice agudo a acuminado, mucronulado, porção distal, com margem irregularmente serreada, escabrosa, nervação acródroma suprabasal perfeita, 3 nervuras principais, face adaxial estrigosa (tricomas tectores 3-celulares com bossas inconspícuas, base cônica cercada por 2 séries de células), face abaxial híspida, nervuras estrigosas (tricomas tectores 3- ou 4-celulares, com bossas inconspícuas, base estreitamente cônica, cercada por uma série de células), com tricomas glandulares. Inflorescência botrióide ou tirsóide, 40-
$45 \mathrm{~cm}$ compr.; paracládios ascendentes, superiores terminando acima do capítulo terminal, estriados, vilosos, os de $1^{\text {a }}$ ordem $6-40 \mathrm{~cm}$ compr., os de $2^{\mathrm{a}}$ ordem ca. 1,5 cm compr.; pedúnculo terminal ca. 3,5 cm compr.; brácteas foliáceas, alternas ou opostas, com tricomas glandulares curtamente pedicelados na face abaxial. Capítulos ca. $3 \mathrm{~cm}$ diâm., radiados, subtendidos por uma bractéola linear, 3-5 mm compr.; invólucro ca. 10 mm diâm., campanulado; brácteas involucrais reflexas na floração, 3 ou 4 séries, as da $1^{\text {a }}$ série 5-7 mm compr., lanceoladas a oval-lanceoladas, foliáceas em 3/4superiores, coriáceas, face abaxial com base estriada, estrigosa, ápice agudo, mucronado, estrigiloso, cilioladas a ciliadas, nas demais séries lanceoladas ou oblongas com base estriada, ápice foliáceo, agudo a longamente acuminado, mucronado, estrigiloso, ciliadas; brácteas da $2^{\mathrm{a}}$ série $7-8 \mathrm{~mm}$ compr., da $3^{\mathrm{a}}$ e $4^{\mathrm{a}}$ séries 8-9 mm compr.; receptáculo convexo, páleas 7-9 mm compr., oblongas, 6 ou 8 nervuras, carenadas, ápice agudo, escariosas, estrigilosas na porção superior externa. Flores do raio ca. 12, em 1 verticilo, corola ca. $10 \times 4-5 \mathrm{~mm}$, limbo oblongo, ápice curtamente 2-partido, glabro, nervuras ca. 10, esparsamente setosas, tubo ca. $1 \mathrm{~mm}$ compr., viloso; flores do disco, com corola 4,5-5 mm, compr. tubo ca. $8 \mathrm{~mm}$ compr., face externa com tubo, base, nervuras e lobos estrigilosos; anteras de base curtamente sagitada, terminando um pouco acima ou na base do colar filetal; estilete com espessamento suprabasal largamente fusiforme, estilopódio $0,08-0,1 \times 0,16-0,20$ mm. Cipselas 3,5-4 mm compr., obovóides, levemente trigonais, estriadas, seríceas a setosas, carpopódio espesso; pápus amarelado 2-aristado, aristas desiguais, firmes, unidas às escamas laterais, a menor 1-1,5 mm compr., a maior 1,5-3 mm compr., estreitamente triangulares, com carena estrigilosa, escamas 4-6 pares, 0,5-1 mm compr., unidas na base ou até próximo ao ápice lacerado.

Conhecida apenas pelo material-tipo, coletado com flores senis e frutos. Parece ser extremamente rara, ou é possível que esteja extinta, pois não foi encontrada durante as quatro expedições efetuadas naquela região do Rio Grande do Sul.

Espécie morfologicamente semelhante a Viguiera procumbens, da qual se diferencia pelas brácteas involucrais internas agudas a longamente acuminadas e pelas aristas do pápus, que são robustas, carenadas e unidas às escamas laterais, enquanto em $V$. procumbens todas as brácteas possuem ápice agudo e as aristas do pápus são delicadas e livres. 

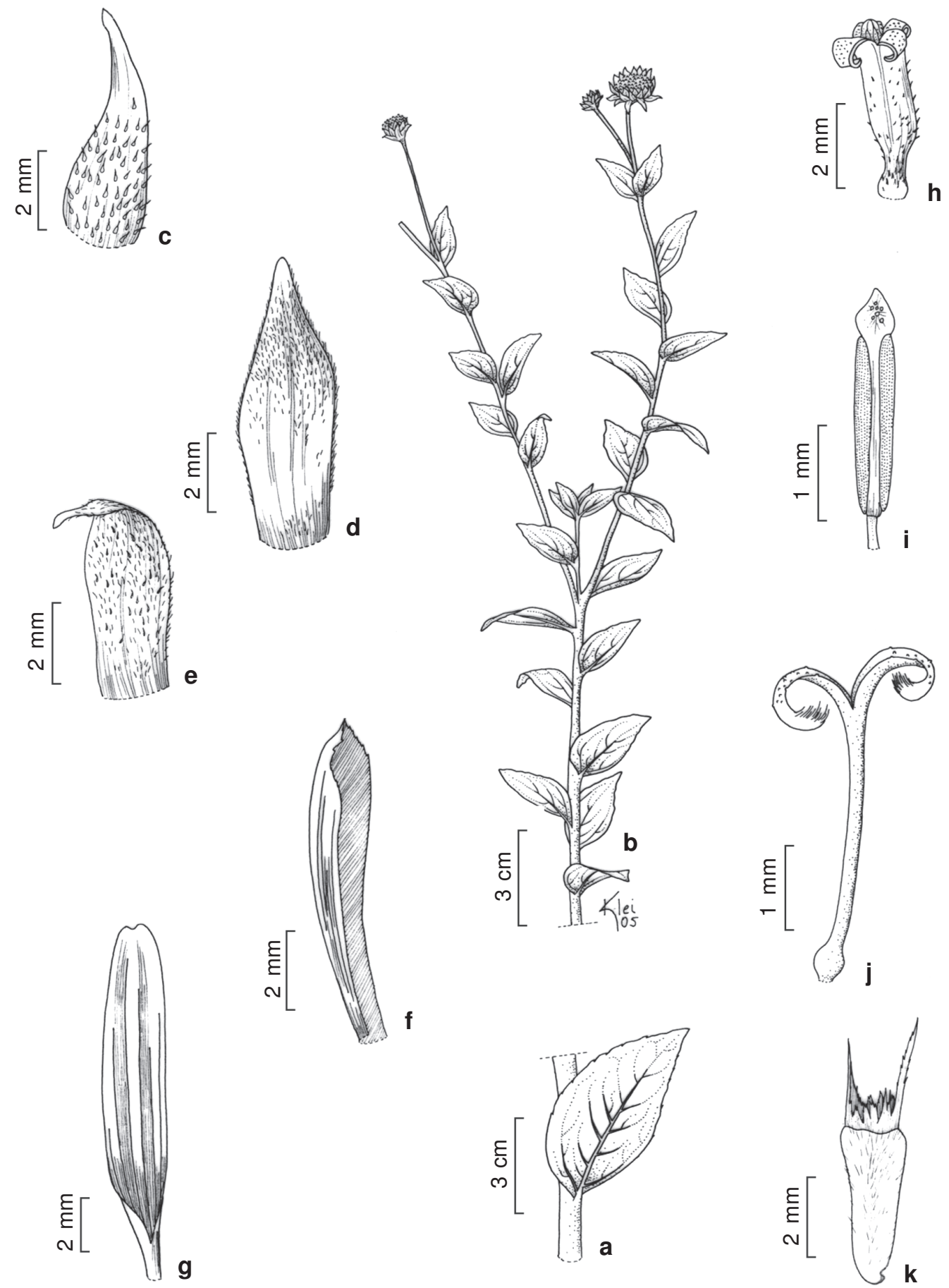

Figura 2 - Viguiera meridionalis - a. segmento de ramo aéreo; b. ramo florífero; c-e. brácteas involucrais; f. pálea; g. corola do raio; h. corola do disco; i. antera; j. estilete; k. cipsela (Hagelund s.n., ICN 124881).

Figure 2 - Viguiera meridionalis - a. portion of aerial branch; b. flowering branch; c-e. phyllaries; f. palea; g. ray corolla; h. disk corolla; i. anther; j. style; k. cypsela (Hagelund s.n., ICN 124881). 
Viguiera rubra Magenta \& Pirani, sp. nov. Tipo: BRASIL. SÃO PAULO: Pirassununga, estrada para a Cachoeira das Emas, km 5,5, 21 ${ }^{\circ} 57^{\prime} 04,3^{\prime \prime} \mathrm{S}$, 47²2'47,4'W, 17.III.2002, fl. e fr., M. Magenta \& J. Magenta 388 (holótipo SPF!; fotografias do holótipo $\mathrm{K}$ !, $\mathrm{SPF}$ !; isótipos $\mathrm{GH}^{*}, \mathrm{~K}$ !, $\mathrm{NY}^{*}$ ). $\quad$ Fig. 3

A Viguiera robusta Gardner affinis, sed capitulo discoideo, corolla vinacea, squamulis lateralibus papporum ad apicem erosis cum aristis unitis differt.

Ervas a subarbustos 0,6-2 $\mathrm{m}$ alt.; ramos aéreos eretos, cilíndricos canaliculados, vilosos, entrenós 1,5-3,5 cm compr.; caule subterrâneo levemente espessado; raízes adventícias sem espessamentos. Folhas discolores a levemente discolores, alternas ou inferiores raramente opostas, sésseis ou pecíolo 1-2 mm compr.; lâmina $2-8 \times 1,5-4,5 \mathrm{~cm}$, elíptica a largamente elíptica, oval ou raramente oval-lanceolada, base arredondada, levemente cordada ou atenuada, geralmente cuneada, ápice agudo a arredondado, porção distal com margem esparsamente denteada, esparsamente estrigilosa, nervação acródroma basal ou suprabasal perfeita, face adaxial reluzente, com tricomas muito esparsos (3-celulares, sem bossas, base cônica a cilíndrica, cercada por uma série de células), face abaxial hirsuta a vilosa, com tricomas glandulares e tectores (estes 4- ou 5-celulares, sem bossas, base cilíndrica a estreitamente cônica, cercada por uma série de células). Inflorescência botrióide ou tirsóide, 15-50 cm compr.; paracládios eretos, os superiores terminando acima do capítulo terminal, canaliculados, hirsutos a vilosos, os de $1^{\mathrm{a}}$ ordem 7,5$50 \mathrm{~cm}$ compr., $2^{\mathrm{a}}$ ordem 4-12 cm compr.; pedúnculo terminal $0,3-7 \mathrm{~cm}$ compr.; bractéas esparsas, 7-10 mm compr., alternas, foliáceas. Capítulos discóides, 2-2,5 cm diâm.; invólucro 8-10 mm diâm., estreitamente campanulado a campanulado; brácteas involucrais reflexas na floração, em 4 ou 5 séries, oblongas a levemente ovais ou às vezes levemente obovais, base canaliculada, 3 nervuras evidentes, foliáceas em 1/2superior, coriáceas ou da série interna às vezes escariosas, face adaxial glabra, face abaxial com nervuras esparsamente híspidas, porção apical às vezes hispídula ou estrigilosa, margem longamente ciliada, ao menos na porção superior, brácteas da $1^{\text {a }}$ série 4-6 mm, ápice obtuso mucronado, demais com ápice obtuso a agudo, brácteas da $2^{\text {a }}$ série 6-8 $\mathrm{mm}$ compr., da $3^{\mathrm{a}}$ série $9-10 \mathrm{~mm}$ compr., da $4^{\mathrm{a}}$ e $5^{\mathrm{a}}$ séries 9 12 mm compr.; receptáculo convexo, páleas $7-8 \mathrm{~mm}$ compr., oblongas a oblanceoladas, ápice arredondado a truncado, mucronado, carena estrigosa, 12 ou 14 nervuras esparsamente estrigilosas. Flores 40-75, porção distal vinácea, corola 5-5,5 mm compr., tubo
1,2 mm compr., esparsa a moderadamente setoso, lobos estrigilosos; antera de base curtamente sagitada, terminando abaixo da base do colar filetal; estilete com alargamento basal estreitamente cônico, espessado na base, estilopódio $0,10-0,12 \times 0,30-0,54$ mm. Cipselas 3-5 mm compr., obovóides a estreitamente obovóides, levemente trigonais, estreitamente estriadas, esparsa a moderadamente seríceas (tricomas dourados); carpopódio delgado médio; pápus amarelado com manchas vináceas, aristas marginais 2, desiguais, unidas às escamas laterais, a menor 2-3 mm compr., a maior 3,5-4 mm compr., triangulares a lanceoladas, base alargada, nervura e margem estrigilosas, escamas em 3 ou 4 pares, 15-18 mm compr., unidas até o ápice eroso. Material examinado: BRASIL. MATO GROSSO DO SUL: Três Lagoas, Horto Santa Luzia, 2005'S, 51 ${ }^{\circ} 53^{\prime} \mathrm{W}$, 12.V.1993, fl. e fr., A.D. Caliente 298 (HISA, UEC). SÃO PAULO: Matão, Rodovia Faria Lima km 1, 13.IV.1981, fl. e fr., H.F. Leitão Filho et al. 12470 (UEC). Mogi Guaçu, Reserva Biológica da Fazenda Campininha, 8.IV.1980, fl., W. Mantovani 519 (SP); beira de estrada, 8.VI.1980, fl., B.C. Lopes 11439 (UEC). Pirassununga, Cerrado de Emas, 2202'S, 47³0'W, 4.V.1994, fl. e fr., M. Batalha \& W. Mantovani 89 (SP).

Coletada nos estados de Mato Grosso do Sul e São Paulo, em pontos isolados, em cerrado ralo, com flores e frutos de março a junho. De acordo com os critérios da IUCN, é uma espécie vulnerável, por distribuição restrita e tamanho populacional reduzido.

Esta espécie de folhas com lâmina de face abaxial reluzente tem morfologia semelhante à de Viguiera robusta, mas apresenta capítulos discóides e mais estreitos, com flores de corola vinácea quando jovens. Além disso, as aristas são unidas às escamas laterais, que apresentam ápice eroso; em V. robusta as aristas são livres e as escamas têm ápice lacerado. Na análise filogenética efetuada por Magenta (2006), V. rubra emergiu como espécie-irmã de V. vernonioides Baker, espécie do Mato Grosso, que tem capítulos radiados com 3 séries de brácteas involucrais, pela semelhança na forma do ápice e indumento da face abaxial das brácteas involucrais.

Viguiera veredensis Magenta \& Pirani, sp. nov. Tipo: BRASIL. MINAS GERAIS. Chapada Gaúcha, Parque Nacional Grande Sertão Veredas, estrada que liga Chapada Gaúcha a Formoso, 15²2’49,9”S, 4556'18,1'W, 21.IV.2003, fl., M. Magenta \& J. Magenta 664 (holótipo SPF!; isótipo K!). Fig. 4

$A$ Viguiera robusta Gardner affinis, sed foliis chartaceis dorso hispidis, pedunculis terminalibus longis, bracteis indumento albido, floribus parvis differt. 

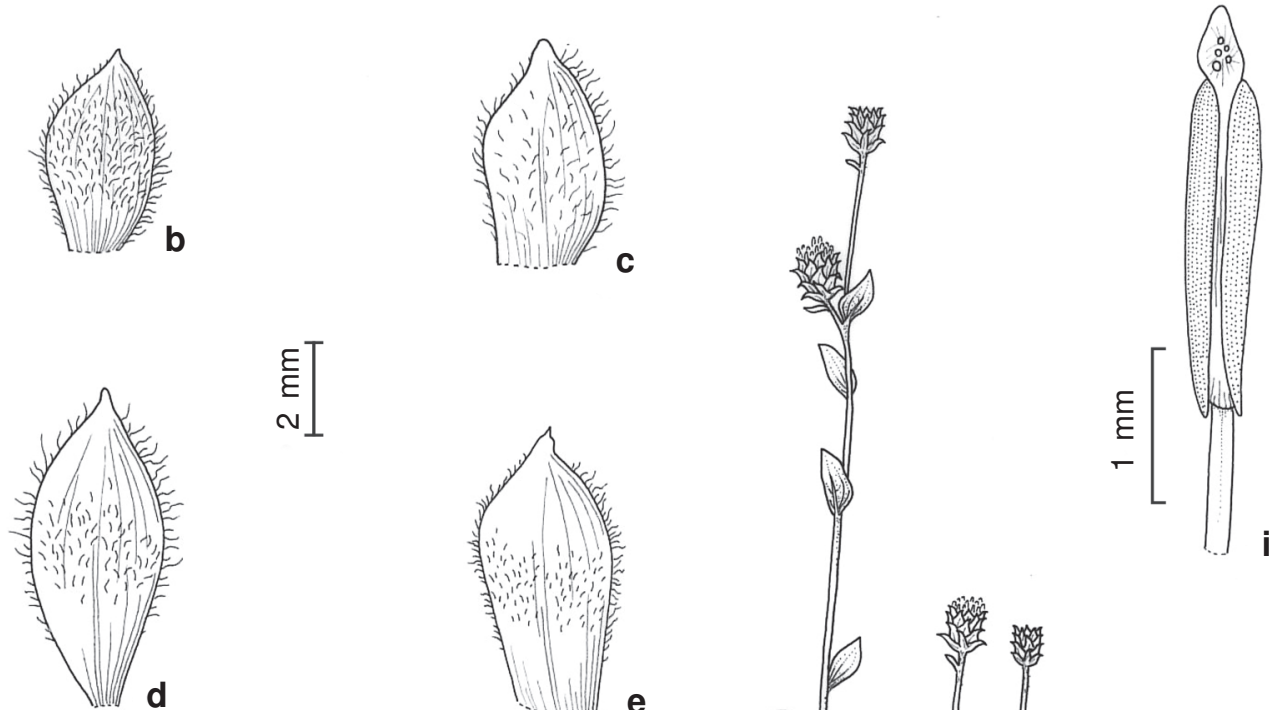

$\varepsilon$
$\Sigma$
$\sim$
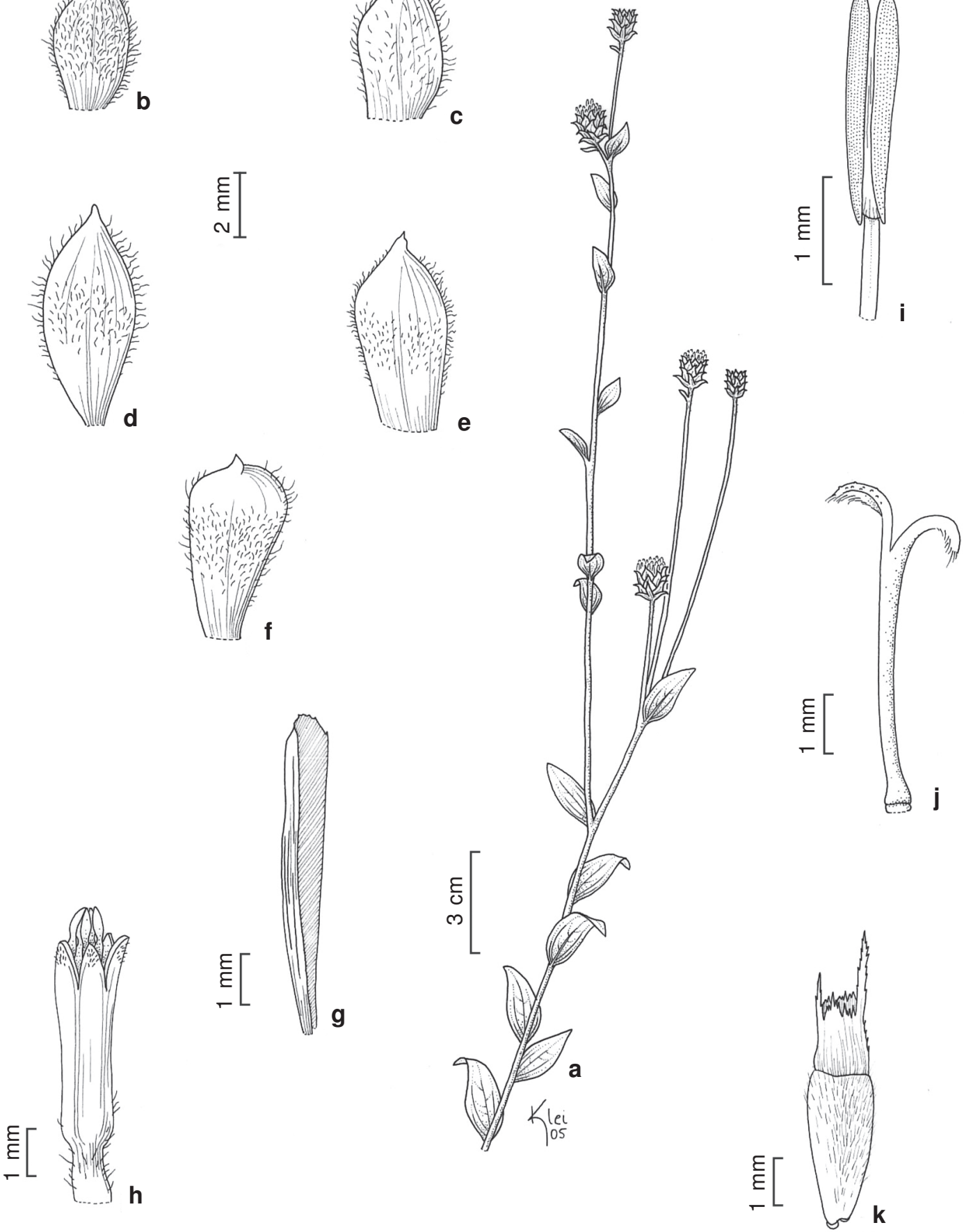

Figura 3 - Viguiera rubra - a. segmento de ramo aéreo e ramo florífero; b-f. brácteas involucrais; g. pálea; h. corola; i. antera; j. estilete; k. cipsela (Magenta \& Magenta 388).

Figure 3 - Viguiera rubra - a. portion of aerial branch and flowering branch; b-f. phyllaries; g. palea; h. corolla; i. anther; j. style; k. cypsela (Magenta \& Magenta 388).

Rodriguésia 61(1): 001-011.2010 
Erva a subarbusto 1-1,5 m alt.; ramos aéreos levemente vináceos, eretos, cilíndricos, canaliculados, densamente híspidos, entrenós 1,53,5 cm compr.; caule subterrâneo pouco espessado; raízes adventícias sem tuberosidade ou com leve espessamento uniforme. Folhas levemente discolores, basais e superiores alternas, medianas opostas, sésseis ou pecíolo 1-2 mm compr.; lâmina 2,5-10 $\times 1-3 \mathrm{~cm}$, oblonga a oval, base levemente arredondada, ápice agudo, mucronulado, margem esparsamente denteada ou serreada na porção distal, cartácea, nervação acródroma basal a suprabasal perfeita, 3 nervuras principais, face adaxial híspida, tricomas tectores 3-celulares (sem bossas ou com bossas inconspícuas, base cilíndrica a levemente cônica, às vezes levemente adpressa, cercada por 2-3 séries de células), face abaxial vilosa e com tricomas glandulares diminutos na nervação terciária, tricomas tectores 3-celulares (com bossas inconspícuas, base cônica, cercada por 2-3 séries de células). Inflorescência botrióide ou tirsóide, 25$55 \mathrm{~cm}$ compr.; paracládios eretos, os superiores terminando acima do capítulo terminal, $13-22 \mathrm{~cm}$ compr., poligonais, canaliculados, esparsamente hirsutos; pedúnculo terminal 9-25 cm compr.; brácteas opostas foliáceas, esparsas. Capítulos 1,52 cm diâm., radiados; invólucro 10-12 mm diâm., largamente campanulado a semigloboso, brácteas involucrais adpressas na floração, em 3 séries, base canaliculada com 3 nervuras destacadas, imersas, ápice obtuso, conspicuamente mucronado, inteiramente foliáceas, cartáceas, duas séries externas com porção inferior ciliolada e porção superior ciliada, face adaxial com ápice esparsamente estrigiloso, face abaxial albo-estrigosa, especialmente na porção superior, na $1^{\text {a }}$ série 3-5 mm compr., oblongas a ovais, na $2^{\text {a }}$ série 4-6 mm compr., ovais a largamente ovais, na $3^{\text {a }}$ série $4-8 \mathrm{~mm}$ compr., obovais a ovais, cilioladas, porção superior estrigosa; receptáculo convexo; páleas 6-7 mm compr., oblongas, hialinas, ápice truncado, eroso, 6 ou 8 nervuras, escariosas, carena estreita e porção superior estrigilosas. Flores do raio 11-12, em 1 verticilo; tubo ca. $1 \mathrm{~mm}$ compr., corola $6-7 \times 2,8-3$ $\mathrm{mm}$, limbo oblongo, ápice arredondado, emarginado, face adaxial glabra, face abaxial com tricomas glandulares, ca. 10 nervuras, hispídulas; flores do disco 70-75, corola 4,5-5 mm compr., tubo ca. $1 \mathrm{~mm}$ compr., face externa com lobos esparsamente hispídulos; antera de base curtamente sagitada, terminando acima da base do colar filetal; estilete sem alargamento, estilopódio ca. $0,1 \times 0,36$ mm. Cipselas jovens 3,5-5 mm compr., obovóides, estriadas, dourado-seríceas, carpopódio médio, pápus estramíneo 2-aristado, aristas marginais levemente desiguais, 1,3-1,4 mm, livres, margem e nervura estrigosas, escamas 6 ou 7 pares, 0,5-1 mm compr., unidas até próximo ao ápice lacerado.

Material examinado: BRASIL. BAHIA: Cocos, 1446'37'S, 4556'45"W, 15.V.2001, fl.e fr., R.C. Mendonça et al. 4277 (HEPH, IBGE, US); 1459'17’'S, 4553'39”'W, 17.V.2001, fl. e fr., R.C. Mendonça et al. 4338 (HEPH, IBGE, RB, US). MINAS GERAIS: Parque Nacional Grande Sertão Veredas, 15¹9'56"S, 4559’00”'W, 29.IV.1999, fl., R. Rodrigues-da-Silva et al. 243 (HEPH, IBGE, US); 15²2'49,9”'S, 4556'18, 1'W, 21.IV.2003, fl., M. Magenta \& J. Magenta 665 (SPF).

Aparentemente rara, é encontrada no norte de Minas Gerais e no sul da Bahia, em cerrado típico com solo arenoso, em altitudes variando de 730 a $880 \mathrm{~m}$, com flores e frutos em abril e maio.

Espécie morfologicamente próxima de Viguiera robusta, da qual se diferencia pelas folhas cartáceas com face adaxial híspida, pelo pedúnculo terminal da inflorescência alongado (9-25 cm compr.), pelas brácteas involucrais com indumento esbranquiçado e ainda pelas flores menores, com corola do raio de 6-7 $\mathrm{mm}$ de comprimento. Viguiera robusta possui folhas coriáceas com face adaxial estrigosa ou raramente setosa, pedúnculo terminal com $1-5 \mathrm{~cm}$ de comprimento, brácteas involucrais com indumento cinéreo e flores do raio com 8,5-12 mm de comprimento.

\section{Combinações novas}

Viguiera goyasensis (H.Rob. \& A.J.Moore) Magenta \& Pirani, comb. nov. Rhysolepis goyasensis H.Rob. \& A.J.Moore, Proc. Biol. Soc. Wash. 117(3): 436. 2004. Tipo: BRASIL. GOIÁS: Serra Geral do Paraná, ca. 3 km S of São João da Aliança, near Riacho, gallery forest and adjacent cerrado, 15.III.1971, fl. e fr., H.S. Irwin et al. 31821 (holótipo US*; isótipos MBM!, NY*, UB, US*).

Material examinado: BRASIL. GOIÁS: São João d'Aliança, estrada para Vãozinho, 9.II.1994, fl, G. Hatschbach \& Silva 60230 (BR, CTES, K, MBM). Corrente, 20.II.2000, fl, G. Hatschbach et al. 70471, (MBM).

Coletada apenas no município de São João da Aliança, no sudoeste do estado de Goiás a cerca de 850 m, em simpatria com Viguiera gardneri Baker, da qual se diferencia principalmente pelas folhas oblongoelípticas a oval lanceoladas com margem inteira, invólucro densamente viloso e aristas do pápus unidas às escamas laterais; $V$. gardneri tem folhas oblongas a largamente oblongas, geralmente com dentes esparsos, invólucro estrigoso ou viloso apenas na porção 

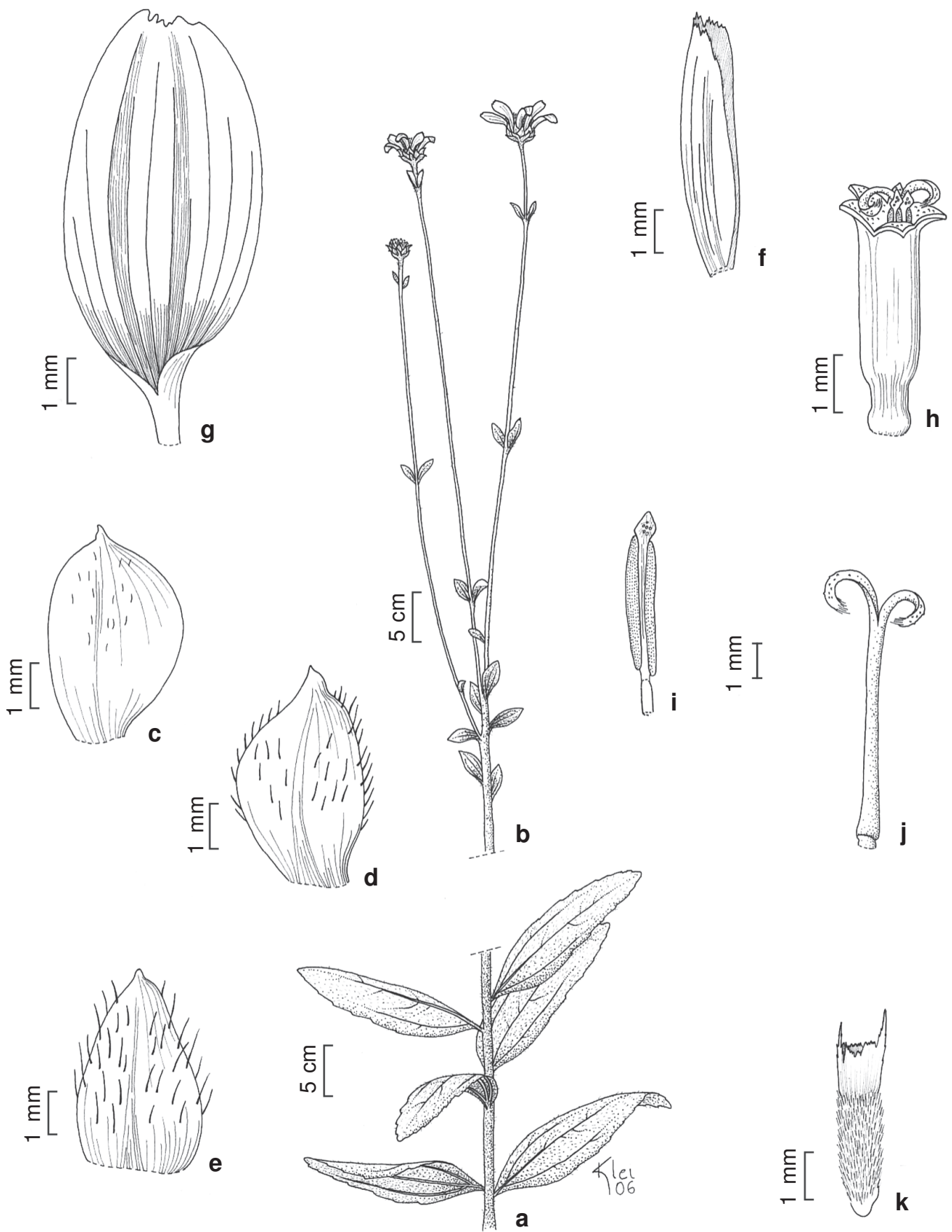

Figura 4 -Viguiera veredensis - a. segmento de ramo aéreo; b. ramo florífero; c-e. brácteas involucrais; f. pálea; g. corola do raio; h. corola do disco; i. antera; j. estilete; k. cipsela (Magenta \& Magenta 664).

Figure 4 - Viguiera veredensis - a. portion of aerial branch; b. flowering branch; c-e. phyllaries; f. palea; g. ray corolla; h. disk corolla; i. anther; j. style; k. cypsela (Magenta \& Magenta 664). 
superior e pápus com aristas livres. Floresce em fevereiro e frutifica em março. A restrição de sua ocorrência e o tamanho populacional reduzido, indicam que a espécie é vulnerável à extinção, segundo os critérios da IUCN.

Viguiera laxicymosa (H.Rob. \& A.J.Moore) Magenta \& Pirani, comb. nov. Rhysolepis laxicymosa H.Rob. \& A.J.Moore, Proc. Biol. Washington 117(7): 440. 2004. Tipo: BRASIL. MINAS GERAIS: Joaquim Felício, Serra do Cabral, estrada para Francisco Dumont, campo rupestre, 16.III.2001, G. Hatschbach et al. 72088 (holótipo MBM!; fotografia do holótipo SPF!; isótipo US*). Material examinado: BRASIL. MINAS GERAIS: Joaquim Felício, Serra do Cabral, próximo do Rio Embaiassaia, 6.V.2004, fl., G. Hatschbach et al. 77443 (MBM); 7.V.2004, fl. e fr., G. Hatschbach et al. 77447, 77478 (MBM).

Endêmica da Serra do Cabral, em Minas Gerais, onde é encontrada em campo cerrado e campo rupestre, a cerca de $950 \mathrm{~m}$; coletada com flores e frutos imaturos em maio. A espécie se enquadra na categoria vulnerável, segundo os critérios da IUCN.

Robinson \& Moore (2004) descreveram as folhas como alternas, mas em todo o material examinado, incluindo o holótipo, as folhas basais são opostas. Diferencia-se de Viguiera robusta e $V$. gardneri pelo tamanho reduzido dos capítulos e flores e pelos paracládios delicados e, de V. rubra, pela presença de flores liguliformes.

Viguiera santacatarinensis (H.Rob. \& A. J. Moore) Magenta \& Mondin, comb. nov. Rhysolepis santacatarinensis H. Rob. \& A.J. Moore, Proc. Biol. Soc. Wash. 117(3): 441. 2004. Tipo: BRASIL. SANTA CATARINA: Serra do Faxinal (Mun. Praia Grande), paredões rochosos, 1.200 m, 15.IV.1993, fl. e fr., G. Hatschbach et al. 59135 (holótipo MBM!; isótipo US).

Material selecionado: BRASIL. RIO GRANDE DO SUL: Bom Jesus, Serra da Rocinha para Bom Jesus, 18.II.1955, fl., B. Rambo 56807 (PACA). Morrinhos do Sul, na subida da trilha Tajuva-Josafá, XII.1995, fl., $M$. Sobral \& J.A. Jarenkow 8014 (ICN). São José dos Ausentes, estrada São José-Timbé do Sul a $7 \mathrm{~km}$ da bifurcação Cambará-São José dos Ausentes, 11.XII.2003, fl. e fr., M. Magenta \& J. Magenta 706, 707 (SPF). SANTA CATARINA: Bom Jardim da Serra, beira de estrada na Serra do Rio do Rastro, I.2000, fl., M. Sobral et al. 9008 (ICN). Lauro Muller, Serra do Rio do Rastro, 3.IV.1957, fl., L.B. Smith \& R. Klein 12339 (LP, US). Timbé do Sul, Serra da Rocinha, $28^{\circ} 48^{\prime} 40,4$ 'S, $49^{\circ} 55^{\prime} 38,8^{\prime \prime} \mathrm{W}, 27 . \mathrm{III} .2002$, fl. e fr., M. Magenta \& $J$. Magenta 410 (SPF).
Espécie vegetativamente semelhante a espécies do gênero Verbesina L.. As brácteas involucrais cirrosas são características do gênero Helianthus, do qual Viguiera é muito próximo. No entanto, o hábito subarbustivo e o pápus persistente não deixam dúvidas quanto ao seu posicionamento em Viguiera. Nas análises filogenéticas com base em morfologia (Magenta 2006), emergiu como espécie-irmã de um clado contendo uma espécie nova e Viguiera vernonioides (análises com 68 e 106 terminais). Compartilha com esta última a presença de inflorescências botrióides, com paracládios terminando acima do capítulo terminal, capítulos com brácteas involucrais levemente apressas na floração, páleas do receptáculo com ápice expandido mucronado, cerca de oito flores do raio e cipselas seríceas, com pápus de ápice lacerado.

Encontrada apenas nos estados de Rio Grande do Sul e Santa Catarina, nas escarpas da Serra Geral, em altitudes compreendidas entre 400 e $1.200 \mathrm{~m}$.

\section{Agradecimentos}

Agradecemos ao Departamento de Botânica da Universidade de São Paulo, onde foi desenvolvida a maior parte da tese de doutorado da primeira autora, que originou parte dos resultados deste trabalho. Ao IBAMA, a concessão das licenças de coleta em parques nacionais. Ao Instituto de Botânica de São Paulo, a autorização de coleta na Reserva Biológica e Estação Experimental de Mogi Guaçu. Aos curadores de todos os herbários visitados, especialmente $\mathrm{BR}, \mathrm{K}, \mathrm{M}$ e $\mathrm{P}, \mathrm{o}$ acesso às coleções e obras históricas e utilização das instalações e infraestrutura. Ao Dr. David John Nicholas Hind, a criteriosa coorientação da tese de doutorado da primeira autora. À Dra. Ils Iob Boldrini, as sugestões e revisão do texto da descrição de Viguiera knobiana. Ao Dr. Rafael Trevisan, a elaboração da diagnose em latim de $V$. knobiana. Aos ilustradores Kley Souza e Caroline Leuchtenberger. O segundo autor agradece ao CNPq pelo subsídio com Bolsa de Produtividade em Pesquisa.

\section{Referências}

Barroso, G.M.; Peixoto, A.L.; Ichaso, C.L.F.; Costa, C.G.; Guimarães, E.F. \& Lima, H.C. 1991. Sistemática de angiospermas do Brasil. UFV, Imprensa Universitária, Viçosa, v.3. 326p.

Blake, S.F. 1918. A revision of the genus Viguiera. Contributions from the Gray Herbarium of Harvard University 54: 1-205. 
Bremer, K. 1994. Asteraceae: cladistics and classification. Timber Press, Portland, 752p.

Harris, J.G. \& Harris, M.W. 2001. Plant identification terminology: an illustrated glossary. 2 ed. Spring Lake Publishing, Spring Lake, 206p.

Magenta, M.A.G. 2006. Viguiera Kunth (Asteraceae Heliantheae) na América do Sul e sistemática das espécies do Brasil. Tese de Doutorado. Universidade de São Paulo, São Paulo. 339p.

Radford, A.E.; Dickison, W.C.; Massey, J.R. \& Bell, C.R. 1974. Vascular plant systematics. Harper \& Row Publ., New York.

Robinson, H. \& Moore, A.J. 2004. New species and new combinations in Rhysolepis (Heliantheae Asteraceae). Proceedings of Biological Society of Washington 117: 423-446.

Roque, N.; Keil, D.J. \& Susanna, A. 2009. Illustrated glossary of Compositae. In: Funk, V.A.; Suzanna, A.; Stuessy, T.F. \& Bayer, R. J. (eds.). Systematics, evolution, and biogeography of Compositae. International Association for Plant Taxonomy, Vienna. Pp. 781-806.

Schilling, E.E. \& Panero, J.L. 1996. Relationships in Heliantheae subtribe Helianthinae based on chloroplast DNA restriction site analysis. In: Hind, D.J. \& Beentje, H.J. (eds.). Compositae: systematics proceedings of the international Compositae conference. Vol. 1. Royal Botanic Gardens, Kew. Pp. 361-376.

Schilling, E.E. \& Panero, J.L. 2002. A revised classification of subtribe Helianthinae (Asteraceae-Heliantheae). I. Basal lineages. Botanical Journal of the Linnean Society 140: 65-76.

Snaydon, R.W. 1984. Infraespecifc variation and its taxonomic implications. In: Heywood, V.H. \& Moore, D.M. (eds.). Current concepts in plant taxonomy. Academic Press, London. Pp. 203-218.

Stace, C.A. 1980. Plant taxonomy and biosystematics. Edward Arnold, London. 279p.

Thiers, B. 2009. Index Herbariorum: A global directory of public herbaria and associated staff. New York Botanical Garden's Virtual Herbarium. Disponível em <http://sweetgum. nybg.org/ih/>. Acesso em janeiro de 2009.

Weberling, F. 1989. Morphology of flowers and inflorescences. Cambridge University Press, Cambrige. 